Warszawa PZWS, 1966. - 203 s. 10. Plany studiow I programy nauczania przedmiotow kierunkowych// Kieruntk studiow Wychowanie Techniczne. Studia magisterskie. Uniwersytety I wyzszeszoly pedagogiczne, MNSzWiT, Warszawa, 1979. - S. 4-7.

УДК $378.011 .3: 373.3-051$

Вікторія Желанова

\title{
ФЕНОМЕН «КОНТЕКСТ» У МІЖДИСЦИПЛІНАРНОМУ ВИМІРІ
}

Желанова В. В. Феномен «контекст» у міждисциплінарному вимірі.

У представленій статті здійснено розгляд поняття «контекст» відповідно до феноменології лінгвістики (лінгвістичний контекст), психолінгвістики (екстралінгвальний контекст), філософії (індивідуальний смисловий контекст), психології (смислоутворювальний контекст), педагогіки (професійний контекст). Доведено, що поняття контекст у сучасному науковому просторі вийшло за межі свого традиційного лінгвістичного й психолінгвістичного розуміння та отримало загальнонаукове, зокрема, психолого-педагогічне, трактування. 3'ясовано, що міждисциплінарне розуміння категорії контекст синтезується саме в його педагогічному визначенні як смислоутворювальної категорії.

Ключові слова: міждисциплінарний аналіз, контекст, типи контексту, контекстне навчання.

Желанова В. В. Феномен «контекст» в междисциплинарном измерении.

В представленной статье рассмотрен феномен «контекст» в соответствии с феноменологией лингвистики (лингвистический контекст), психолингвистики (экстралингвистический контекст), философии (индивидуальный смысловой контекст), психологии (смыслообразующий контекст), педагогики (профессиональный контекст). Доказано, что понятие «контекст» в современном научном пространстве вышло за пределы своего традиционного лингвистического и психолингвистического понимания и получило общенаучное, в частности, психологопедагогическое, трактование. Выяснено, что междисциплинарное понимание категории контекст синтезируется именно в его педагогическом определении как смыслообразующей категории.

Ключевые слова: междисциплинарный анализ, контекст, типы контекста, контекстное обучение.

Zhelanova V. V. The phenomenon of «context» in an interdisciplinary dimension.

The article deals with the phenomenon of «context» in accordance with the phenomenology of linguistics (linguistic context), psycholinguistics (extralinguistic context), philosophy (individual semantic context), psychology (semantic context), education (professional context). It is proved that the concept of context in the modern scientific space has gone beyond its traditional linguistic and psycholinguistic understanding and received general scientific understanding and, in particular, psychological and pedagogical, interpretation. It was found out that an interdisciplinary understanding of the category context was synthesized in its definition as a pedagogical sense-category.

Key words: interdisciplinary analysis, context, context types, contextual learning.

Міждисциплінарна методологія $є$ грунтовною в дослідженні педагогічних феноменів. Оскільки саме вона відбиває тенденції сучасної педагогічної теорії та практики, що пов'язані 3 їх фундаменталізацією, поліпарадигмальністю та 
поліпідхідністю. Ми розуміємо міждисциплінарність як методологічний принцип сучасного наукового дослідження, що передбачає широке використання наукової інформації незалежно від іiі дисциплінарної належності, $€$ синтезом наукових досягнень $з$ різних дисциплін. У поданій статті нами здійснено міждисциплінарний аналіз поняття «контекст». Такий дослідницький крок зумовлений двома обставинами. По-перше, поняття «контекст» $\epsilon$ семантичним складником досліджуваного нами феномену «контекстне навчання». По-друге, міждисциплінарна та інтеграційна природа поняття «контекст» розкривається вже в його походженні. Оскільки етимологія слова «контекст» пов'язана з латинським contextus, яке утворено за допомогою префікса «соп», що позначає спільність дії, зв'язок, взаємозв'язок, та іменника «textus»- тканина, сплетіння. Прикметник «contexta» позначає зв'язний, безперервний; іменник «contextus» має значення «зчеплення», «з'єднання», «зв'язок» [3]. Тобто міждисциплінарність поняття «контекст» міститься вже в його етимології.

Дослідження феномену «контекст» представлені такими науковими напрямами: лінгвістичне трактування (Ж. Вандрієс, В. Колшанський, Є. Кротевич, А. Новиков, І. Сиров, Н. Шведова); психолінгвістичні дослідження (В. Бєлянін, Л. Виготський, Т. Дейк, Л. Карпенко, О. Леонтьєв, С. Рубінштейн); філософське розуміння (І. Гердер, В. Дільтей, С. Лебедєв, К. Поппер, Р. Рорті); психологічні дослідження (А. Адлер, Т. Дубовицька, М. Коул, С. Мадді, А. Маслоу, Р. Нісбетт, Л. Росс, Є. Титченер); педагогічне трактування (А. Вербицький, Н. Жукова, Г. Лаврентьєв, Н. Лаврентьєва, М. Макарченко). Проте за такої зацікавленості поняттям «контекст» у різних науках, його цілісний міждисциплінарний аналіз залишається поза увагою дослідників.

Метою статті є міждисциплінарний аналіз поняття «контекст» відповідно до феноменології лінгвістики, психолінгвістики, філософії, логіки й методології, психології й педагогіки.

До наукового термінологічного апарату поняття «контекст» прийшло 3 лінгвістики та психолінгвістики. Лінгвістичне трактування поняття «контекст» пов'язано 3 розглядом його як фрагмента тексту, як умови зв'язності тексту, як інтертекстового явища, як джерела семантичного значення. Проте лінгвістика досліджує текст і відповідно контекст як продукт діяльності автора, абстрагуючись від його особистості.

Дещо інші підходи ми спостерігаємо в психолінгвістиці, у якій текст постає як процес і результат взаємодії між матеріальним «тілом тексту» й людиною. Вітчизняна психолінгвістика базується на теорії мовної діяльності, найважливішим внеском у яку є праці Л. Виготського, О. Леонтьєва, С. Рубінштейна, та розуміє «контекст» як закінчений у смисловому відношенні відрізок писемної мови (тексту), що дає можливість точно встановити значення тих окремих слів та речень, що входять у нього. Отже, контекст у психолінгвістиці постає переважно в тій же ролі, що й у лінгвістиці, тобто контекст - це текст, за винятком одиниці аналізу. Однак, ураховуючи предмет психолінгвістики, контекст може створюватися особистістю мовця, ситуацією, а також включати позамовні чинники. Як бачимо, у психолінгвістиці поняття контексту розширилося i змістилося 3 формального боку тексту до екстралінгвальних чинників, як-от: особистість і ситуація.

У філософії поняття контексту відривається від тексту й мови та стає більш загальним поняттям. Відомі філософські підходи до контексту як набору характеристик, які уточнюють зміст феномену, локалізують його в просторі та часі (В. Семенова); визначають межі пізнання світу, надають цілісність сприйняття подій та об'єктів (Д. Дьюї). У філософії контекст також пов'язується з процесом пізнання. 
Розуміння й урахування контексту, у якому виявляється або існує той чи той феномен, дозволяє зробити пізнання більш об'єктивним та різнобічним. О. Никифоров, аналізуючи процес пізнання 3 філософських позицій, уводить поняття «індивідуальний смисловий контекст» і на його основі будує семантичну концепцію розуміння. Під індивідуальним смисловим контекстом дослідник розуміє світ індивідуальної свідомості, відкриту систему, що змінюється впродовж усього життя індивіда та включає особистісний життєвий досвід, цілі, стосунки, цінності тощо. У процесі взаємодії 3 навколишньою дійсністю індивід накладає на неї свій індивідуальний контекст і завдяки цьому розуміє іiі, наповнює певними смислами явища й предмети навколишнього світу [7].

У логіці та методології наукового пізнання контекст розуміється як окреме міркування, фрагмент наукової теорії або теорія загалом; як доповнення до основного семантичного значення, яке має слово або речення, узяті самі по собі. Контекст надає їм додаткового значення, більше того, він може суттєво змінити основне значення слів і речень. Тому в різних контекстах слова й речення можуть набувати різних значень. Іноді контекст цілком надає значення певному терміну. У таких випадках говорять про контекстуальне визначення терміна. При цьому використовують такі словосполучення: «розглядати в контексті», не «можна вирвати 3 контексту», «контекстуальне значення», «поза контекстом», «розуміти контекстуально». Існують також англійські терміни «contextualize» (контекстуалізувати), тобто помістити в контекст, i «contextualization» (контекстуалізація). Питання про контекстуальне значення наукових термінів привертає велику увагу в методології наукового пізнання у зв'язку з аналізом розвитку наукового знання, переходом термінів зі старої теорії в нову та зміною їхнього значення при таких переходах [4].

Отже, беручи до уваги розглянуті підходи, що стосуються трактування поняття «контекст», відзначимо, що воно є одним 3 найбільш продуктивних міждисциплінарних феноменів, що часто використовується в лінгвістиці, психолінгвістиці, логіці, філософії. Але в сучасний період розвитку науки поняття «контекст» виходить за межі традиційного трактування й фактично постає як загальнонаукова, зокрема психологічна та педагогічна, категорія, опора на яку, як доводить А. Вербицький, відкриває нові перспективи в науковому пізнанні й освітній практиці [2].

У психології звернення до контексту як до предмета аналізу $є$ менш популярним, ніж у лінгвістиці, психолінгвістиці та філософії. Проте контекст у психології $є$ набагато ширшим поняттям, ніж у зазначених науках. Так, А. Ребер у Великому психологічному словнику визначає контекст як подію й процеси (фізичні й психічні), що характеризують конкретну ситуацію й здійснюють вплив на поведінку індивіда; специфічні обставини, за яких відбувається дія чи подія [8, c. 371].

На думку А. Вербицького та В. Калашникова, психологічний контекст $\epsilon$ системним, двояким явищем, а саме: 1) для самого суб'єкта контекст - це психічний механізм, що забезпечує когнітивні процеси (за типом гештальта), а також бере участь в усіх феноменах психіки (за типом установки); 2) для спостерігача-дослідника - це теоретичний конструкт, що відбиває певний спосіб моделювання психічних процесів [1, с. 135$]$.

Залежно від предмета вивчення психологи розглядають індивідуальноособистісний контекст і соціальний контекст, у які включають будь-які явища, що дозволяють пояснити зміст предмета вивчення або обгрунтувати смисл його появи. 
У психологічній літературі наголошено на смислоутворювальному впливові різного роду контекстів на процеси психіки, свідомості та діяльності людини (Д. Брунер, Л. Виготський, О. Леонтьєв, С. Рубінштейн та ін.), зокрема пізнавальної діяльності (Т. Дубовицька), хоча впершесмислоутворювальна роль контексту була сформульована у працях філософів (М. Бахтін, В. Біблер, Ю. Лотман). Завдяки контексту людина виявляється здатною передбачати й осмислено інтерпретувати події та явища, що вже настали, виявляти їхній смисл. Перш ніж починати будь-які дії, людина прагне зібрати всю можливу контекстну інформацію. При цьому, якщо в пам'яті людини не утримується контекст, у якому вона діяла, порушується цілеспрямованість іï поведінки. Проте смисли є динамічними утвореннями, специфіка їх динаміки криється в зміні різних контекстів (Л. Баткін), а також у їхньому розширенні. Явище «розширення контексту» досконало розкрито у фундаментальній праці Д. Леонтьєва «Психологія смислу». На його думку, більш глибоке й повне пізнання смислових зв'язків відбувається за рахунок вербалізації вихідних смислів у процесі розширення контексту, а також урахування нових смислових контекстів [6].

У педагогіку поняття «контекст» прийшло порівняно недавно, тому воно ще не набуло певного статусу й у педагогічних словниках не описується. Педагогічні аспекти категорії «контекст» найбілыш удало розкрито в дослідженнях А. Вербицького та представників його наукової школи (Н. Борисова, Н. Жукова). На думку науковця, контекст - це система внутрішніх і зовнішніх умов та чинників поведінки й діяльності людини, яка впливає на сприйняття, розуміння й перетворення суб'єктом конкретної ситуації, що визначає смисл та значення цієї ситуації як цілого, так і певних іï компонентів [1, с. 33-34]. Відповідно виокремлюються зовнішній і внутрішній контексти. Внутрішнім контекстом він уважає систему унікальних для кожної людини психофізіологічних та особистісних особливостей i станів, іiі настанов та відносин, знань та досвіду; зовнішнім предметні, соціокультурні, просторово-часові та інші характеристики ситуації, у якій вона діє. На всіх рівнях психічного віддзеркалення внутрішній і зовнішній контексти у їх взаємодії виконують смислоутворювальну функцію [5, с. 7]. Такий розподіл контексту $є$ досить абстрактним та формальним, тому науковець вносить певні уточнення й внутрішній контекст ототожнює 3 предметно-професійним, а зовнішній iз соціальним контекстом.

Звернемо увагу на те, що педагогічного втілення категорія контекст отримала саме в теорії та технології контекстного навчання, де великої ваги набуває створення контексту професійної діяльності, тобто професійного контексту. Поняття «професійний контекст» із загальнопрофесійних позицій досліджено А. Вербицьким. Він розглядає зазначене поняття як смислоутворювальну категорію, що впливає на процес оволодіння реальною предметною діяльністю завдяки надання їй особистісного смислу.

Крім цього, суттєвим є дослідження різноманітних типів контексту в зазначених галузях наукового знання. Надамо їх таксономію відповідно до аспекту дослідження контексту в певних науках, а саме:

- лінгвістика i психолінгвістика - лінгвістичний, екстралінгвістичний, психолінгвістичний, когнітивно-прагматичний типи контексту;

- філософія - історичний, індивідуальний смисловий контекст;

- психологія - соціальний, культурний, соціокультурний, життєвий, індивідуально-особистісний; екзистенціальний, ситуаційний, акціональний, психологічний; актуальний та потенційний, смислоутворювальний, контекст спілкування;

- педагогіка - зовнішній (соціальний); внутрішній (предметно-професійний); контекст загальнолюдської культури, соціокультурний контекст; зовнішній 
кроскультурний контекст, внутрішній кроскультурний контекст; контекст культури, ситуативний, особистісний; контекст змісту освіти (соціальний, наукового знання, навчального предмета; дидактичний; особистісної значущості); контролювальний та інформувальний, професійний типи контексту.

Отже, у процесі міждисциплінарного аналізу поняття «контекст» у різних наукових галузях ми з'ясували тенденцію до більш розширеного визначення цього феномену у психології та педагогіці. Так, у лінгвістиці контекст - це лише уривок тексту, умова зв'язності тексту, тоді як у педагогіці - це вже система внутрішніх і зовнішніх умов і чинників поведінки та діяльності людини. Однак для нашого дослідження вагомими й важливими є певні положення з кожної із зазначених наук.

Отже, виходячи з лінгвістичного трактування контексту, значущими є розгляд його як джерела смислу, а також виокремлення функції відбору та актуалізації необхідного значення. Відповідно до цих положень у контекстному навчанні майбутніх учителів початкових класів джерелом смислу $є$ контекст професійної діяльності, а зазначені функції контексту реалізуються в доборі навчальної інформації, що відбиває зміст майбутньої професії.

Щодо психолінгвістики, то ми загострюємо увагу на ідеї про те, що контекст може створюватися і самим суб'єктом, і ситуацією. Тобто набувають вагомості екстралінгвальні чинники, а саме - особистість і ситуація. У досліджуваній нами системі контекстного навчання вже в межах навчальної діяльності академічного типу викладач засобами певної навчальної інформації створює контекст майбутньої професії.

Далі у квазіпрофесійній діяльності в аудиторних умовах моделюються ситуації майбутньої професійної діяльності, що вже створюються спільно викладачем і студентом. Тобто очевидними є екстралінгвальні чинники.

Важливими для нас $є$ положення філософії щодо локалізації контексту у просторі й часі як динамічного явища, а також розгляду його як «фонового середовища». Так, динаміка контекстного навчання збігається 3 динамікою руху різних діяльностей студентів - навчальної академічного типу, квазіпрофесійної, навчально-професійної. Щодо реалізації середовищного підходу, окресленого у філософії, ми наполягаємо на необхідності створення у процесі контекстного навчання майбутніх учителів початкових класів рефлексивно-контекстного середовища.

3 погляду логіки та методології наукового пізнання вагомими для нас $є$ ідеї щодо розгляду контексту як фрагмента наукової теорії або теорії загалом, а також контекстуалізації, контекстуального визначення термінів. Такими в нашому дослідженні є рефлексивно-контекстний підхід, рефлексивно-контекстне середовище, контекстуалізація навчальної інформації, що об'єднуються в теорії та технології контекстного навчання майбутніх учителів початкових класів i становлять їхнє поняттєво-категоріальне поле.

Утім більш близьким до проблеми нашого дослідження $є$ психологічне трактування контексту як психічного механізму, що забезпечує когнітивні процеси (за типом гештальта) та бере участь у всіх феноменах психіки (за типом установки). Вагомими для нас також $є$ психологічні положення щодо переплетіння діяльності й контексту, тобто контекстуалізації дії; смисло-утворювального впливу різного роду контекстів на процеси психіки, свідомості та діяльності людей; думка про те, що динаміка смислів криється в розширенні контекстів (Д. Леонтьєв).

Відтак, міждисциплінарне розуміння категорії контекст синтезується в його педагогічному трактуванні як смислоутворювальної категорії, як системи внутрішніх і зовнішніх умов життя та діяльності людини, яка в конкретній ситуації визначає смисл 
і значення цієї ситуації і загалом, і компонентів, що до неї входять.

Отже, аналіз категорії «контекст» і феноменів, що стоять за ним, відповідно до феноменології лінгвістики, психолінгвістики, філософії, логіки та методології, психології та педагогіки, дає підставу вважати, що поняття контекст у сучасному науковому просторі вийшло за межі свого традиційного лінгвістичного й психолінгвістичного розуміння та отримало загальнонаукове, зокрема психологопедагогічне, трактування. Дослідження саме педагогічних аспектів поняття контекст $€$ перспективним у наших наступних працях.

\section{Література}

1. Вербицкий А. А. Категория «контекст» в психологии и педагогике /

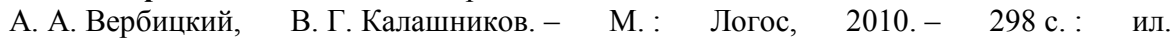
2. Вербицкий А. А. Новая образовательная парадигма и контекстное обучение/ А. А. Вербицкий. - М. : Исслед. центр проблем качества подготовки специалистов, 1999. - 75 с. 3. Дворецкий И. Х. Латинско-русский словарь: более 200000 слов и словосочетаний / И. Х. Дворецкий. - [10-е изд., стер.]. - М. : Рус. яз. Медиа, 2006. 843, [2] с. 4. Ивин А. Словарь по логике / А. Ивин, А. Никифоров. - М. : Гуманит. изд. центр «Владос», 1997. - 384 с. 5. Контексты в образовании субъекта: межвуз. сб. науч. тр. / под ред. А. А. Вербицкого, Н. В. Жуковой. - М. : РИЦ МГОПУ им. М. А. Шолохова, 2005. - 96 с. 6. Леонтьев Д. А. Психология смысла: природа, строение и динамика смысловой реальности / Д. А. Леонтьев. - М.: Смысл, 2003.- 487 с. 7. Никифоров А. Л. Семантическая концепция понимания / А. Л. Никифоров // Загадка человеческого понимания / под ред. А. А. Яковлева. - М., 1991. - С. 72-95. 8. Ребер А. Большой толковый психологический словарь : в 2 т. / Артур Ребер ; пер. с англ. Е. Ю. Чеботарева. - М. : ООО «Изд-во АСТ», 2003. - Т. 1 : А - О. - 591, [1] с.

УДК $378.1 ; 437.6$

Тетяна Ключкович

\section{РОЗВИТОК СИСТЕМИ ПЕДАГОГІЧНОЇ ОСВІТИ В КОНТЕКСТІ РЕФОРМУВАННЯ ВИЩОЇ ШКОЛИ У СЛОВАЦЬКІЙ РЕСПУБЛІЦ}

Ключкович Т. В. Розвиток системи педагогічної освіти в контексті реформування вищої школи у Словацькій Республіці.

У статті розглянуто розвиток словацької вищої школи і педагогічної освіти зокрема в контексті постсоціалістичної модернізації та європейської інтеграції. Зроблено висновок про значні зміни в системі вищої освіти Словаччини, які зорієнтовані на оновлення іiі структур та нормативно-правового забезпечення, модернізацію змісту і методів підготовки фахівців.

Ключові слова: Словацька Республіка, реформа вищої освіти, європейська інтеграція, Болонський процес, педагогічна освіта.

Ключкович Т. В. Развитие системы педагогического образования в контексте реформирования высшей школы в Словацкой Республике.

В статье рассмотрено развитие словацкой высшей школы и педагогического образования в частности в контексте постсоциалистической модернизации и европейской интеграции. Сделан вывод о значительных изменениях в системе высшего образования Словакии, которые 'ориентированы на обновление ее структур и нормативно-правового обеспечения, модернизацию содержания и методов подготовки специалистов.

Ключевые слова: Словацкая Республика, реформа высшего образования, 